\title{
The Grotesque World in The Heart is a Lonely Hunter
}

\author{
Huimin Liu ${ }^{1}$ \\ ${ }^{1}$ Beijing International Studies University, China \\ Correspondence: Huimin Liu,English Language Literature and Culture Department,Beijing International \\ Studies University, Dingfuzhuang Nanli No.1, Chaoyang District, Beijing City, China. E-mail: \\ m18853813896@163.com
}

Received: October 30, 2021

Accepted: December 20, $2021 \quad$ Online Published: January 7, 2022

doi:10.5539/ells.v12n1p49

URL: https://doi.org/10.5539/ells.v12n1p49

\begin{abstract}
This article is going to explore the reasons leading the figures grotesque and the way out of such world, with the help of Bakhtin's theory of grotesque realism, via linking the duality of physical part with the grotesque to analyze the three main characters' physical characteristics, social relationships and mental world. Singer, Mick and Biff are the distinct characters in Carson McCullers's novel The Heart is a Lonely Hunter. Their lives are shot through with frustration and discouragement and the intense privacy of their inner lives gives the reader the impression that they are isolated, lonely beings. They try to build connections with others but eventually they fail. The following are the reasons: Firstly, they cannot identify themselves with the majority due to their physical problems, which further lead to their mental crisis. Secondly, they are alienated from the majority in society while they communicate with the ones who cannot end their isolation, which enforces their alienation. Finally, loneliness grips them so powerfully that they cannot come out of their grotesque dreaming world centering on the truth or idea or purpose they have created for themselves. Therefore the way out is to experience the social reality, to express ideas, share care and love with others. Through the interpretation of this novel, the point of this article is to explain the reasons and the ways out of alienation, the keyword in the grotesque world.
\end{abstract}

Keywords: The Heart is a Lonely Hunter, Carson McCullers, alienation, grotesque realism, Bakhtin

\section{Introduction}

Lula Carson Smith McCullers was born in 1917, in Columbus, Georgia. Her major works' settings were in her native South suffused with the atmosphere of the region. Amid the wave of the Southern Renaissance by 1920s, due to the influence of commercial and industrial economy and the intrusion of modern civilization, the traditional way of life in South America is eroded and undermined. As a unique and representative writer of South America ranked after Faulkner, Porter, McCullers her works greatly concerned the issues of that time, "racial and gender inequality, classism and economic injustice, the hypocrisy of religious fundamentalism, anti-intellectualism, xenophobia, and homophobia" (Dews, 2019, p. 281). Living in a unique historical background, she also suffered special personal experiences. During her childhood, Carson was a particular girl treated as a freak just because of her over height that confused her a lot. She usually pretended to cover her inner isolation and once fell in love with her piano teacher Mary·Tucker. The homosexual love at her early age had a great impact on her later writing skills. Furthermore, her personal life experiences determined her works, and also characterized some autobiographical aspects of the novel.

The theme of McCullers' works is "exploringisolation, loneliness and fulfilled desire by describing these characters living in the spiritual wasteland who attempt to construct their own identity and be accepted by others but eventually fail" (Yi, 2018, p. 4). That is to say, the current life is meaningless and futile to those people who felt homeless and alienated. They cannot escape from the barren spiritual land, nor change the surrounding environment. Leslie Fiedler has described American literature as "a literature of darkness and the grotesque in a land of light and affirmation" (p. 29). More specifically, it is the literature of the Southern Renaissance that has become the synonymous with the grotesque, and Carson McCullers' work typifies both. Major critical studies of her work comment on the grotesque and its link with the strange world of the gothic, or its function as a bleak and violent response to the modern world. In sum, the grotesque, not only has a symbolic role in McCullers' novels and short stories, but it also forms a negative, unproductive view of the world and human activity.

McCullers' use of the grotesque can be clearly understood when one examines the meaning of the word. The 
Oxford English Dictionary defines grotesque as the following: "in popular language, figures or designs characterized by comic distortion or exaggeration. In a wider sense, of design or form characterized by distortion or unnatural combinations; fantastically extravagant; bizarre; quaint." In his book The Grotesque, Philip Thomson defines the term specially in connection with literature: the grotesque is more than "laughable" or a "necessary affinity with the fantastic" (p. 8).

In contemporary literature, the grotesque "can best be summed up as alienation, "Something which is familiar and trusted is suddenly made strange and disturbing" (Thomson, 1972, p. 59). Some of McCullers' characters have physical problems: being a dwarf, being overly tall, etc. In this sense, these characters are grotesques because they are "characterized by comic distortion or exaggeration". Besides, these physical abnormalities only emphasize the characters' more important spiritual abnormalities. Thus, her characters do fit Thomson's definitions of grotesque.

For the most part, McCullers' characters are lonely people who are living in small Southern towns and trying to find themselves. McCullers' characters are distorted; they are not whole human beings. As Chester E. Eisinger explains, they are "half-people, their deficiencies prevent them from realizing their humanity; their course in life is errant, unpredictable, painful" (p. 252). In their search to make themselves complete, the characters attempt to join with others, but the choice each makes of a mate, the person with whom each hopes to find communion, usually brings more frustration and further alienation. Thus, McCullers uses her idea of the grotesque - complete alienation caused by someone trying to find him or herself and find love- to express her idea of spiritual isolation.

The Heart Is a Lonely Hunter is Carson McCullers' first novel and one of her most famous novels. This novel came out in 1940. From then on, Carson McCullers' successful writing career began. This novel gives us a day, a year, and a day in the lives of five characters: Singer, Mick, Brannon, Blount, and Dr. Copeland. Their lives are shot through with frustration and discouragement and the intense privacy of their inner lives gives the reader the impression that they are isolated, lonely beings. The central theme of The Heart is a Lonely Hunter is the individual's spiritual alienation, but meantime McCullers also poses subordinate themes "such as adolescent initiation, the dangers of capitalism, and the evils of racism" (Champion, 1991, p. 48). These underlying themes rotate around the central idea alienation in much the same manner as "the people of this book can be described as being like the spokes of a wheel—with Singer representing the center point" (Outline, p. 143). In this novel, the deaf-mute Singer becomes the focus of a circle of negative people. The loneliness and alienation theme runs through the whole story. At first, two deaf-mutes, John Singer and Spiros Antonapoulos live together. One day, Antonapoulos is ill and is taken to the state insane asylum. Singer moves to another flat and meets four special lonely people who view Singer as the God. At last, Singer kills himself after he came to know Antonapoulos died. The four people lose their reliance again. In the novel, Carson McCullers depicts a grotesque world. Most people think that this novel is negative and tedious. However, the frustrations they experience are most often a product of their very passionate attempts to follow their desires or convictions. Moreover, McCullers employs several devices which work against the sense of loneliness and which lend a tenuous sense of unity, an echoing of sensibility, to the discrete voices of the characters.

The purpose of this article is to demonstrate that the grotesque life lies at the center of the novel The Heart is a Lonely Hunter. The following is to explore the three main characters in this novel. All three become frustrated, alienated when fail to communicate with the ones who they feel can end their isolation.

\section{Literature Review}

Carson McCullers is famous for her personal experiences and her deep understanding on human life. She has been always popular among readers. Scholars are attracted by her unique perspective, the freaks, the alienated and the mystic American Southern town in her works. Carson McCullers has been a pain for the critics since her first publishing work The Heart Is a Lonely Hunter in 1940. The bitter controversies she triggers involve a wide range of subjects from her status, themes, forms, strategies, to the social and political aspects of her works.

Louis D. Rubin Jr. draws on McCullers' personal situation such as her illness, marriages, bisexuality, and her Southern experience to make a better understanding of her work. McCullers receives praises for her construction of her art "out of the South, but not out of its history" (Rubin, 1996, p. 123). Gleeson-White explores The Heart Is a Lonely Hunter as a work of southern gothic tradition and McCullers' characters as grotesques (Gleeson-White, 2003, p. 3). Alexander Steele traces a Deaf-oriented rhetoric within The Heart Is a Lonely Hunter, examining the consequences of reading and understanding deafness metaphorically, both on and beyond the fictive page. Waggoner posits that Singer enacts a kind of listening that he defines as feminist, since it exhibits feminist principles of egalitarianism, parity, and equality throughout the conversation rather than 
creating a hierarchy of power between speaker and listener in which the speaker retains the authority. Saxton holds that Singer etc. are Christ figures, they are diseased Christs who are unable, or not unwilling to save themselves. Stacey Reece combines the theory of Marxism on alienation to discuss how the main characters are alienated in the materialistic society. The analysis offers a glimpse into the social condition in the Great Depression era, the issue of poverty, oppression, the exploitation of racism and capitalism.

Concerning the work The Heart Is a Lonely Hunter, the concentrations of the critical studies are plural from its themes and characters, to social and political aspects. The perspectives that critics employ to this work vary from Marxism, feminism, gender studies, to New Historicism. These critical reviews have broadened the horizon for the present study of the novel The Heart Is a Lonely Hunter.

\section{The Analysis of the Three Figures}

\subsection{John Singer's Grotesque World as a Mute}

John Singer, a mute, thin and tall person is very intelligent, "his eyes had a quick, intelligent expression" (p. 3). The eyes express an individual, so to speak, Singer demonstrates himself as a quick-witted man before others. $\mathrm{He}$ is the central figure for the other four ones - each of whom is satisfied when talking to him and anybody in the town can conceive some traits that they presuppose in him, "The Jews said that he was a Jew. The merchants along the main street claimed he had received a large legacy and was a very rich man. It was whispered in one brown beaten textile union that the mute was an organizer for the C.I.O." (p. 182). Many lonely people from the town use the mute's silence as an opportunity to believe that he understands them, and this imagined connection gives them relief from the pain of isolation. But in fact, Singer is an orphan who was left very young and placed in an institution for the deaf. Besides, he doesn't understand others' talking and actually he even doesn't care about their matters. What he concerns is his "only friend" (p. 182). Antonapoulos, with whom he has been living for ten years. Singer closes his own world to others apart from Antonapoulos but he "never knew just how much his friend understood of all the things he told him. But it did not matter" (p. 2). Singer, like the other freaks who talks with him talks with Antonapoulos who never really responds to his talking matters. In this grotesque chain of hunting loneliness, Singer's hands, replacing his mouth play the leading role to hunt and to be hunted.

Singer has been introduced through his relationship with Spiras Antonapoulos. Singer has not always been a real mute and he has been taught to speak but he could never be used to speaking with his lips. "It was painful for him to try to talk with his mouth, but his hands were always ready to shape the words he wished to say" (p. 10). Mouth cannot be ignored in the study of the grotesque, through which enters the world to be swallowed up, and "of all the features of the human face, the nose and mouth play the most important part in the grotesque image of the body" (Bakhtin, 1984, p. 316). Mouth as one of the tunnels from the inside of the body to the outside, through it there is an interchange and an inter-orientation and meanwhile the confines between people have been overcome with the words spoken out of mouth. Singer gives up his mouth to talk and replace it with his hands. "Grotesque images may, of course, present other members, organs and parts of the body (especially dismembered parts). but they play a minor role in the drama. They are never stressed unless they replace a leading image" (Bakhtin, 1984, p. 318). Hands should have played minor role for the grotesque image but because Singer's hands replace his mouth to talk, the hands are significant for the talk of Singer, the grotesque figure.

Singer's hands are presented contradictorily, actively and silently. When Singer is with Antonapoulos, his hands move quickly and shape the words he wants to say. However, when he is faced with others apart from Antonapoulos, his hands are still and stuffed into his pockets and he responds to others only with the expression of his eyes. Before Antonapoulos is taken to the asylum, Singer is always talking to him. "His hands shaped the words in a swift series of designs. His face was eager and his gray-green eyes sparkled brightly. With his thin, strong hands he told Antonapoulos all that had happened during the day" (p. 2). After Antonapoulos is taken far away from the town where Singer lives in, the latter visits the former, and as before, his hands talk desperately. "Singer raised his hands timidly and began to speak. His strong, skilled fingers shaped the signs with loving precision" (p. 188). He tells his friend all the people he had met and things he had experienced in the town. When he realizes that he him may be with danger, "Singer stood with his hands dangling loose" (p. 280). His hands' looseness implicates his life's listlessness. On the contrary, when he was with others, "he always kept his hands stuffed tight into the pockets of his trousers" (p. 9).

The hand is the means for Singer to connect with the world, but he stretches out his hands only to Antonapoulos, which signifies that Singer's world is only open to him. This also can explain why Singer dies when he is told the news of Antonapoulos' death. That he stuffs his hands into the pockets is like he closes his mouth as well as his inside world, swallowing up others' words. When being with Antonapoulos, he reaches out his hands to give, 
so to speak, to swallow out what he has taken. On the one hand, Singer's hands have crowned him. His silence with his hands in the pockets makes him seem superior in front of others. For Mick, he knows music; for Jake, he knows revolution; for Doctor Copeland, he knows the Negro's bad conditions. For others in the town each man describes the mute as he wished him to be. Singer is crowned as their king owing to his hands stuffed in pockets, to his silence. On the other hand, his hands degrade him before Antonapoulos. He is not silent and quiet but nervous and passionate to please Antonapoulos with his hands talking. However, Singer's degradation is exactly Antonapoulos' crowning. "In his haste the signs sometimes became blurred and he had to shake his hands and begin all over. Antonapoulos watched him with his dark, drowsy eyes. Sitting motionless in his bright, rich garments he seemed like some wise king from a legend" (p. 191). Hands are the representation of Singer's duality, his talkativeness and silence, playing the dual role of degradation and up gradation for the grotesque, the mute named Singer.

Singer, the lover, creates in his mind a world for himself and his beloved Antonapoulos. He dreams of the Greek constantly and lives only for the times he can be with his friend. Nothing else seems to concern Singer. His hands, which he once cared for meticulously because he used them to communicate with Antonapoulos, become "a torment to him" (p. 345). Singer is alone and lonely with his hands stuffed in his pockets. He is alienated because of his deafness and especially because of his failure even to try to "stretch out his hands" to communicate with those who reach out to him.

\subsection{Mick Kelly's Grotesque World as an Adolescent Girl}

The next character to be discussed is Mick Kelly, the young adolescent girl at the center of the novel. This may seem counter intuitive because, when compared to the other characters, Mick's crisis seems the most personal in nature. She is dealing with the process of changing from an androgynous girl into a feminized woman. At the beginning of the novel, Mick is resistant to this process of becoming a woman. She idealizes her older brother Bill while demonizing her feminized older sisters. When sisters criticize Mick for wearing boyish clothes, Mick replies, "I don't want to be like either of you and I don't want to look like either of you. And I won't. That's why I wear shorts. I'd rather be a boy any day, and I wish I could move in with Bill" (McCullers, p. 42). Mick Kelly perceived freakishness arises from her boyishness, at a moment in her life when she should ideally be entering into womanhood. However, the young girl is freakish not only because of her tom-boyishness but also, paradoxically, because of her emerging femininity and sexuality. As a result, the girl identifies and is identified with freak.

"In the dynamics of freakishness, the category of "normal' is contingent on the category of the "abnormal"" (Gleeson-White, 2003, p. 12). That is to say, normality and freakdom or abnormality are interconnected. It is the tension between Mick's tom-boyishness and the ideal of the southern lady that most obviously makes manifest this interconnected dichotomy.

It seems that Mick fails to fulfill the requirements of womanhood "membership" due to their male identification, clearly at odds with images of proper femininity, the ideal image of the good little woman. In the South, while tom-boyishness may have been acceptable in the young girl, at puberty she was expected to begin the metamorphosis into southern womanhood. But, since Mick perseveres with mas- culine appearance and behavior, society brands her freak. This idea of freakishness is reflected in Mick's older and "feminine" sister Etta Kelly's criticism of Mick's persistent masculinity: "It makes me sick to see you in those silly boy's clothes. Somebody ought to clamp down on you, Mick Kelly, and make you behave," Etta said. "Shut up," said Mick. "I wear shorts because I don't want to wear your old hand-me-downs" (p. 41). What Etta wants to warn Kelly is that somebody ought to make Mick become a true woman and behave girlishly.

There is in fact several moments when Mick do attempt to conform to the cultural ideal of womanhood as articulated by Etta and Bernice. To do so, she must first cleanse herself of freakishness by rejecting her boyishness. Before her prom party guests arrive, Mick "went into the bathroom and shucked off her old shorts and shirt and turned on the water. She scrubbed the rough parts of her heels and her knees and especially her elbows. She made the bath take a long time" (p. 97). Ironically, when Mick does attempt to conform to societal demands, she unwittingly undermines the notion of ideal womanhood. For example, Mick reveals femininity's impracticability as she dresses gorgeously for her prom party in "Etta's long blue crepe de chine evening dress and some white pumps and a rhinestone tiara" (p. 97). Once the neighborhood children begin to destroy the grownup party atmosphere, Mick becomes aware of the constraints of feminine attire. Wanting to jump into a roadside ditch, she realizes that with "her tennis shoes she would have landed like a cat—but the high pumps made her slip" and so she finds herself. Having torn the hem of the evening dress and lost her tiara, she puts her old shorts and shirt back on, although "she was too big to wear shorts anymore after this" (p. 105). It becomes 
painfully clear that womanhood, here signaled by dress, is a hindrance to the hopes and plans of the young tomboys.

Mick is a lonely young girl who finds it difficult to open up to others. Although she lives in a house full of people, she does not feel that she belongs to any group. At one point, she wants to belong but only feels loneliness: "It was funny, too, how lonesome a person could be in a crowded house" (p. 195). Mick knows she wants more than her family can offer. This desire grows and grows within her only to make her frustrated. Through music, she tries to express herself and to make a living, but due to no enough money, her music career just stops as an unfinished dream. Not being able to communicate through music, which she feels is the only way she can communicate, Mick becomes confused. The only thing she is sure of is the strange, frustrated, angry feeling that grows within her: "The feeling was a whole lot worse than being hungry for any dinner, yet it was like that. I want - I want-I want—was all that she could think about—but just what this real want was she did not know" (p. 194).

In waking life, Mick is always struggling against the crowd instead of being a member of it. Also, she feels that she is ignored. Finally, she believes that what she wants does not matter. This last belief is reinforced when she must quit school and go to work to help the family. Although she tries to adjust to giving up her dream by telling herself that her work with music was not in vain and that she may get another chance, she feels isolated: "But now no music was in her mind. That was a funny thing. It was like she was shut out from the inside room. It was like the inside room was locked somewhere away from her. A very hard thing to understand. It was like she was cheated. Only nobody had cheated her" (pp. 292-293).

In many ways, then, Mick is as grotesque as the others. Loneliness and frustration dominate her. However, unlike the others, she does not blame her problems on others, and she does not want to cure society or to solve the problems of others. She simply wants to understand and better herself.

\subsection{Biff Brannon's Grotesque World as Being Both Sexes}

Biff likes freaks. He is drawn to freaks because he is himself a freak. He is of the both sexes, and what he proofs it himself is that "the part of him that sometimes almost wished he was a mother and that Mick and Baby were his kids" (p. 112). Mentally he tends to be feminine but he physically is very masculine. "He was a hard man of middle height, with a beard so dark and heavy that the lower part of his face looked as though it were molded of iron" (p. 9). Moreover, compared with Singer's hands, Mick's nibbles, his special physical part is "his genitals" (p. 24), the distinctive organ for male. Among the parts of the grotesque body, "the bowels and the phallus, these two areas play the leading role in the grotesque image" (Bakhtin, 1984, p. 317). The phallus, nibbles, or other protruding part of the body expand the body and to link it to other bodies or to the world outside. However, genitals playing the essential role for the Biff's grotesque image, this word only appears once in the novel but the word "nose" appears many times. The grasp of the meaning of the grotesque image's nose is that it "always symbolizes the phallus" (Bakhtin, 1984, p. 316). Biff's different actions to the nose are with regard to his both sexes.

Biff mashes the nose three times as the following: "Biff waited stolidly, his elbow resting on the counter and his thumb mashing the tip of his long nose" (p. 10). "He[Biff] wanted to turn and walk away and yet he only stood there, smiling and mashing his [Harry's] nose with his thumb" (p. 201). "He [Biff] mashed his [Jake's] nose with this thumb until it was white and flat" (p. 295). Besides, he fondles it once: "Thoughtfully Biff fondled the tip of his nose" (p. 12). According to the dictionary, the word fondle means to touch (someone or something) sexually and the word mash, means to flirt with or seek the affection of the opposite sex. Taken the symbolic meaning of nose as phallus into consideration, Biff's action to fondle and mash his own or other male's nose is equal to flirt with himself and other males sexually. This grotesque action can be explained by his both sexes and mentally he identifies himself as a female.

Concerning about his wife, Biff never fondles or mashes the nose, but only rubs his noses. "Biff would stand looking at her [Alice's] for a long time, rubbing his nose thoughtfully" (p. 103). The rubbing of nose is not a special action for Biff on the ground that he often rubs his nose when he is observing and thinking. So to speak, he has no special or sexual feeling for his wife. But towards Mick, his actions of the nose shifts with Mick's sexual appearances. When he thinks that Mick is both sexes, who "looks as much like an overgrown boy as a girl" (p. 112), he "laid his finger on the side of his nose and cocked his head to one side" (p. 112). Here, "cock", with the meaning of a man's penis together with finger and nose tints the scene with sexual color. However, compared with mashing the nose with thumb, the action of laying his finger on side of nose is more obscure, ambivalent and tender. His love for Mick is dual, on the one hand, due to Mick's boyish appearance, he has the kind of love between man and woman. On the other hand, Mick's childish aspect provokes his maternity and 
therefore he wishes her to be his child. At the end of the novel, when he finds that Mick had grown older, he watches her, "Her rough and childish ways were almost gone. And instead there was something ladylike and delicate about her that was hard to point out" (p. 305) and feels only a sort of gentleness. In him the love between man and woman is finished. "Biff tapped his nose with his forefinger" (p. 305). Compared with the action of laying, tabbing is more dynamic within short time without any feelings. Therefore, he retains aloof and withdrawn and loneliness grips him.

Biff finally fails to build any connection with others, as he described that "This man had a good mind, all right, but he went from one thing to another without any reason behind it at all. He was like a man thrown off his track by something" (p. 10). Biff is alone at the end of the novel. He tries to build communication and connection with others, especially with Mick, but he never overcomes his own world of meditation. Only observing and thinking of others is useless to enter others' bodies or the outside world.

\section{Conclusion}

In the novel The Heart is a Lonely Hunter, each of the characters is frustrated and preoccupied, and that preoccupation makes the characters grotesque. The characters cannot face themselves or any phase of reality. McCullers' characters are grotesque because each is obsessed with one single idea, purpose, or personality trait. Also, because each dwells on the idea, purpose, or trait and fails to communicate effectively with others, each becomes lonely, isolated, and frustrated. Although each of the major characters does attempt to communicate and share with another person, the choice of confidant is a poor one and only adds to the character's frustration, For instance, Singer believes that Spiros Antonapoulos is his best friend and that Antonapoulos understands everything he says and feels. Antonapoulos, however, is self-centered and cares only for what Singer can give him. When Antonapoulos dies, Singer, who is loved and respected by several people, believes he has no purpose in life and kills himself.

Also, Biff, Mick is searching for someone to understand their desires. Each turns to Singer, who, although he can read lips and can even speak, never really understands the others or attempts to verbalize with them because of his obsession with his own purpose in life. When Singer kills himself, the others find themselves again alone and confused. These characters attempt to interact with others, but the relationship is always blocked or misunderstood.

These characters want to express love, but largely because they use almost all of their energies to attempt to flee from reality and to replace it with a dream world centering on the truth or idea or purpose they have created for themselves, they are unable to express it. The characters are obsessed with their ideas and dreams, but they are incapable of expressing their feelings. This desire to communicate along with the inability to communicate either leads the characters to speak out at inappropriate times or to become withdrawn. In either case, they appear both laughable and pitiful - the characteristics of a grotesque - to others. They however, try to transgress their limits, and so to speak, they are on the road of becoming.

\section{References}

Ann, C. (2009). Georgian. University of Georgia Press.

Bakhtin, M. M. (1984). Rabelais and his world (Trans. by Helene Iswolsky). Indiana: Indiana University Press.

Champion, L. (1991). Black and White Christs in Carson McCullers's 'The Heart Is a Lonely Hunter'. The Southern Literary Journal, 24(1), 47-52.

Dews, C. (2019). Carson McCullers (1917-1967) 'The Brutal Humiliation of Human Dignity' in the South. (Chapter) Georgia Women. Ann Short Chirhart \& Kathleen.

Eisinger, C. E. (1963). Fiction of the Forties. Chicago: Universe of Chicago Press.

Fiedler, L. (1967). Love and Death in the American Novel. London: Cape.

Gleeson-White, S. (2003). Strange Bodies: Gender and Identity in the Novels of Carson McCullers. Alabama: The University of Alabama Press.

McCullers, C. (1953). The Heart is a Lonely Hunter. New York: Bantam.

McCullers, C. (1971). Author's Outline of The Mute. In G. S. Margarita (Ed.), The Mortgaged Heart. Boston: Houghton Mifflin.

Reece, S. R. (2003). Hopelessness and Despair: Alienation and Oppression in 'The Heart Is a Lonely Hunter' by Carson McCullers. M.A. Thesis. U of East Tennessee State.

Rubin, Jr., \& Louis, D. (1996). Carson McCullers: The Aesthetic of Pain. In L. C. Beverly \& J. F. Melvin (Eds.), 
Critical Essays on Carson McCullers (pp. 111-123). London: Prentice Hall International.

Saxton, B. (2013). Finding Dostoevsky's 'Idiot' in Carson McCullers's The Heart Is a Lonely Hunter. ANQ: A Quarterly Journal of Short Articles, Notes, and Reviews, 26(2), 103-108. https://doi.org/10.1080/0895769X.2013.777264

Steele, A. (2021). Estrangement and the Consequences of Metaphorical Deafness: Reconsidering The Heart Is a Lonely Hunter. Journal of Literary and Cultural Disability Studies, 15(1), 57-73. https://doi.org/10.3828/jlcds.2021.4

Thomson, P. (1972). The Grotesque. London: Methuen.

Waggoner, K. (2017, 2018). Embodied Listening: Singer as Feminist Listener in The Heart Is a Lonely Hunter. Mississippi Quarterly, 70/71(1), 61-80. https://doi.org/10.1353/mss.2017.0003

Yi, B. (2018). The Analysis of Construction of Black American Cultural Identity in The Heart is a Lonely Hunter. Thesis for the Degree of Master, Northeast Forestry University.

\section{Copyrights}

Copyright for this article is retained by the author, with first publication rights granted to the journal.

This is an open-access article distributed under the terms and conditions of the Creative Commons Attribution license (http://creativecommons.org/licenses/by/4.0/). 